\title{
Moğol İşgali Sırasında Van Gölü Havzası'na Gelen Türk-Moğol Boyları
}

\section{Erol Keleş}

\section{Özet}

XIII. yüzyılın ikinci yarısında meydana gelen Moğol istilası Anadolu'ya çok sayıda Türk ve Moğol kabilesinin gelmesine sebep olmuştur. Moğollar, askeri birliklerini teşkil eden Moğol ve Türk aşiretlerini Anadolu'nun doğu bölgelerine yerleştirdiler. Zira Doğu Anadolu yaylak-kışlak hayat tarzını sürdüren bu aşiretler için uygun özellikleri barındırmaktaydı. Illk kez Celaleddin Harezmşah'ı takip eden Çurmağun Noyan'la birlikte gelen bu topluluklar arasında Uygur, Karluk ve çok sayıda Türkmen topluluğu da vardı. Bu bağlamda Yassıçemen yenilgisinden sonra, çoğunluğu Kanglı ve Kıpçak Türklerinden müteşekkil Harezmli ordusu başıboş bir vaziyette Anadolu'ya dağılmıştı. Selçuklu ve Eyyubi hizmetine alınan bir grup Harezmlilerin Van ve çevresine iskân edildikleri yer adlarından anlaşılmaktadır. Ayrıca Selçuklu fütühatıyla Azerbaycan'a gelen çok sayıda Oğuz boyunun Moğol istilasıyla birlikte Doğu Anadolu'ya ve bilhassa Van Gölü Havzası'na akın ettiği kaynaklarda anlatılmaktadır.

Bölgeye esas büyük nüfusun gelişi Hülegü'nün Batı seferi sonucunda olmuştur. Hülegü'nün ordusunda başta Uyrat, Sulduz, Celayir, Tatar, Sünit olmak üzere çok sayıda Moğol boyu vardı. Bu Moğol kabileleri Van Gölü'nün kuzeyindeki Aladağları yaylak olarak kullanıyorlardı. ilhanlı devletinin yıkılışından sonra da bölgede varlıklarını devam ettireceklerdir. Hülegü yöreyi stratejik öneminden dolayı Ahlat merkezli bir eyalet içerisine aldığı gibi bölgeye Türk ve Moğol boylarını da iskan etmiştir. Akkoyunlu ve Kara Koyunlu Türkmenlerinin de Moğol istilasıyla geldikleri düşünülürse Van Gölü Havzası'nın demografik yapısının nasıl teşekkül ettiği daha iyi anlaşılmaktadır.

Yukarıda bahsi geçen Türk-Moğol boyları, önce İlhanlı devleti içerisindeki taht mücadeleleri, ardından devletin yıkılmasıyla başlayan hâkimiyet mücadeleleri ve nihayet Kara Koyunlu ve Akkoyunlu mücadeleleri sonucunda başta İran ve Orta Anadolu olmak üzere çevreye göç edeceklerdir.

Anahtar Kelimeler: Moğol, Türkmen, Kıpçak, Tatar, Uyrat, Van Gölü Havzası, Kabile.

* Dr., İnönü Üniversitesi, Sosyal Bilimler Enstitüsü, Genel Türk Tarihi Anabilim Dalı, erlkls44@hotmail.com. (Makale Gönderim Tarihi: 07.02.2018; Makale Kabul Tarihi: 20.03.2018) (ORCID ID: 0000-0002-1717-212X).

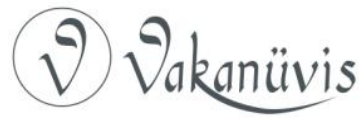




\section{Turk -Mongol Clans That Came to the Van Lake Basin During the Mongol Occupation}

\section{Abstract}

The Mongol invasion, which happened in the second half of 13th century, caused that a lot of Turk-Mongol clans came to the Anatolian. The Mongol put into Mongol and Turk tribes that constituted in their military, to their east area of Anatolian. Because the East Anatolian had appropriate futures for those tribes who had summer posture ana winter quarters way of life. There was much community of Uigur and Karluk and Turcoman among these clans which came with Curmagun Noyan who firstly followed Djelal Ed-Din Khwarazmshah. So, Khwarazm military majority of which composed of Kangly and Qıpcaq Turks had independently spread to the Anatolian after Yassıçemen defeat. It has been understood that some of the Khwarazms who were taken to service of Seljukid and Eyyubi were settled to Van and Its near, from the names of place. In addition, it's told that plenty of Oghuz tribes who came to Azerbaijan with victories of Seljukid surged into the East of Anatolian and especially the Van Lake Basin.

The basic arrival of majority of the population to the area, happened in the result of hülegü's West voyage. There were a lot of Mongol tribes particularly Avirata, Sulduz, Djalair, Tatar and Sunıt. These Mongol clans used the Alatagh in the north of Van lake as summer pasture. They would maintain their existence in the area after The Ilkhanid state was demolished. Because of its strategical importance, at the moment Hülegü took the area in province centered with Khlat settled Turk and Mongol clans to the area, too. If it is considered that, Aq Qoyunlu and Qara Qoyunlu Turkomans came with the Mongol occupation, too, it's comprehended well how demographic structure of the Van Lake Basin was formed.

The Turk and Mongol clans mentioned at above would migrate to environs especially Persia and middle of the Anatolian at the result of firstly struggle, of throne in Persia, then struggle of sovereignty which started with the state's demolishing and finally Qara Qoyunlu and Aq Qoyunlu's struggle.

Keywords: Mongol, Turcoman, Qıpcaq, Tatar, Avirata, Van Lake Basin, Tribe.

Moğol istilasının en önemli sonuçlarınından biri de hiç şüphesiz Anadolu'nun demografik yapısı üzerindeki tesiri olmuştur. Zira bu olay çok sayıda Türk ve Moğol topluluğunun Anadolu'ya akın akın 
gelmesine sebep olmuştur. ${ }^{1}$ Konuyla ilgili olarak bilhassa ülkemizde pek çok çalışma yapılmasına rağmen, bunlar genellikle ya siyasi-askeri açıdan ele alınmış ya da Anadolu'nun tamamına yönelik geniş bir çerçeve çizilerek ortaya konulmaya çalışılmıştır. Hâlbuki önemli yolların güzergâhı üzerinde yer alan ve aynı zamanda yüksek platoları ve geniş otlak alanlarıyla, Moğol işgali sırasında Türkistan'dan gelen Türk ve Moğol kabileleri için aranan özelliklere sahip Van Gölü Havzası, bu kabilelerin yurt tuttuğu veya iskân edildiği bir yöre olması bakımından önem arz etmektedir. Buna rağmen Moğol işgaliyle bahse konu yöreye gelen Türk ve Moğol toplulukları hakkında herhangi bir çalışmanın yapılmamış olması tarafımızdan büyük bir eksiklik olarak değerlendirilmektedir. İşbu çalışmayla sözü edilen sahanın bir nebze de olsa doldurulabileceği düşünülmektedir.

Moğol istilası sırasında Anadolu'ya Türk ve Moğol kabilelerinin ilk gelişi Çurmağun Noyan'ın bölgeye gönderildiği döneme tesadüf etmektedir. Celaleddin Harzemşah'ı takip eden Çurmağun, komuta ettiği yaklaşık 40.000 kişilik bir kuvvetle Doğu Anadolu sınırlarına dayanmıştı. ${ }^{2}$ Bu ordu geri dönmeyeceği için askerler aileleriyle birlikte gelmişlerdi. Hayvan sürüleri ve tüm ağılıklarını yanlarında getirmiş olan bu Moğol birliğinin 200 bin çadır olduğu ve dolayısıyla da bir milyonluk kalabalık bir nüfusu barındırdığı tahmin edilmektedir. ${ }^{3}$ Dört tümenden müteşekkil olan bu ordunun bir tümeni Türk ve Müslüman olan Melikşah adlı bir beyin komutasında, Uygur, Karluk, Türkmen ve Küçey adlı Türk kavimleri ile Kaşgar bölgesinden katılmış olan Türklerden oluşmaktaydı. ${ }^{4}$ Diğer taraftan Moğol ordularından kaçan Oğuz, Karluk, Kıpçak, Kanglı vs. Türk toplulukları Azerbaycan ve

1 Bu konuda geniş bilgi için bkz. F. Sümer, "Anadoluda Moğollar", SAD I, Ankara 1970, s.1vd.

2 Bkz. Alaaddin Ata Melik Cüveyni, Tarih-i Cihangüşa I, (nşr. Mürsel Öztürk), Ankara 1998, s.147.

3 M. Fuad Köprülü, Osmanlı Imparatorluğunun Kuruluşu, (nşr., O. Köprülü), İstanbul 2012, s.91vd; Muammer Gül, Orta Çağlarda Doğu ve Güneydoğu Anadolu ( Tarihi Arka Plan ve XIII -XIV Yüzyıl Moğol Hâkimiyeti), İstanbul 2010, s.194. Çurmağun Noyan'ın batıya gönderilmesi hakkında geniş bilgi için bkz., Abdulkadir Yuvalı, Ilhanlılar Tarihi I, Kayseri 1995, s.28vd.

${ }^{4}$ F. Sümer, "Anadolu'da Moğollar", s.2.

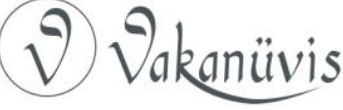


Anadolu'ya göç ettiler. ${ }^{5}$ Celaleddin Harzemşah'ın Moğol baskısından kaçarak Azerbaycan ve Doğu Anadolu'ya gelmesi sebepsiz değildi. Nitekim bölgedeki Türk nüfusunun yoğunluğu O'nun böyle bir tercih yapmasında etkili olmuştu. ${ }^{6}$ Bununla birlikte daha evvel Gürcü ordusu içerisinde kalabalık bir Kıpçak topluluğunun Kür-Çoruh boylarına ve Doğu Anadolu'ya geldikleri bilinmektedir. ${ }^{7}$ Bu bağlamda Moğol işgalinin şahidi Müverrih Vardan Hunlardan ayrılan Kıpçakların Gence'ye gelerek Tatarlara iltihak ettiklerini, bölgedeki Ermeni ve Gürcülere karşı savaştıklarını belirtmektedir ki bu durum bölgede önemli bir Kıpçak nüfusunun varlığını göstermesi bakımından önemlidir. ${ }^{8}$

Celaleddin Harezmşah'ın Yassıçemen (1230) yenilgisi, beraberinde gelen Moğol baskınları ve nihayet Harezmşah'ın ölümü üzerine, büyük ölçüde Kanglı ve Kıpçak Türklerinden müteşekkil ordusu ${ }^{9}$ başıboş bir

5 Bkz. M. Fuad Köprülü, a.g.e, s.88vd; A. Yaşar Ocak, XIII. Yüzyılda Babailer İsyanı, İstanbul 1980, s.37; A. Yuvalı, "Anadolu'nun Türkleşmesi ve Moğollar", Türk Dünyası Araştırmaları, S: 38, İstanbul Ekim-1985, s.98vd; Peter b. Golden, Türk Halkları Tarihine Giriş, (nşr. Osman Karatay), İstanbul 2012, s.301vd, 317vd.

6 Bkz. Salim Cöhce, "Doğu Karadeniz Bölgesinin Türkleşmesinde Kıpçakların Rolü", I. Tarih Boyunca Karadeniz Kongresi Bildirileri (13-17 Ekim1986), Samsun 1988, s. 482.

${ }^{7}$ Kıpçakların bölgeye gelişi ve Kıpçak-Gürcü ilişkileri hakkında geniş bilgi için bkz., M. Fahrettin Kırzıoğlu, Yukarı Kür ve Çoruk Boyları'nda Kıpçaklar (Ahıska/Çıldır Eyaleti Tarihi'nden), Ankara 1992, s.105vd; Z. Velidi Togan, Umumi Türk Tarihine Giriş, İstanbul 1981, s159vd; i. Kafesoğlu, Türk Milli Kültürü, İstanbul 1996, s.179vd; Ahmet Gökbel, Kıpçak Türkleri, İstanbul 2000, s.56vd; Peter B. Golden, "Cumanica I: The Qıpcaqs in Georgia", Nomands and their Neighbours in the Russian Steppe-TurksKhazars and Qipcahaqs, Variorum 2003, s.62; Guili Alasania, "Gürcistan Kıpçakları", Türkler II, Ankara 2002, s.794; A. Nimet Kurat, IV-XVIII. Yüzyıllarda Karadeniz'in Kuzeyindeki Türk Kavimleri ve Devletleri, Ankara 2002, s.84; Mualla Uydu Yücel, ilk Rus Yıllıklarına Göre Türkler, Ankara 2002, s.62vd; Mehmet Eröz, Hırıstiyanlaşan Türkler, Ankara 1983, s.4; Salim Cöhce, a.g.m, s.479vd; Charles J. Halperin, "The Kipçhak Connection: the Ilkhans, the Memluks and Ayn Jalut", Bulletin of The School of Oriental and African Studies, University of London, vol. 63, No.2 (2000), s.234.

8 Bkz. Müverrih Vardan, "Türk Fütühatı Tarihi", (889-1169)", (nşr. Hrand D. Andreasyan), iÜEFY, Tarih Semineri Dergisi I/2, İstanbul 1937, s.223.

9 Esasen Sultan Tekiş'in eşi Terken/Türkan Hatun KanglıTürklerinin Bayat boyuna mensup idi. Bu evlilik çok sayıda Kanglı beylerinin ve topluluklarının Harezmşah devletinin hizmetine girmesine zemin hazırlamıştır. Bkz. en-Nesevi, Celalüttin Harzemşah, (nşr. Necip Asım), İstanbul 1934, s.23; A. Taneri, a.g.e, s.19vd; M. Baron C.

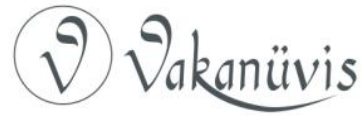


vaziyette Anadolu'ya dağımıştı. ${ }^{10}$ Sayıları hakkında çeşitli rakamlar telafuz edilen bu Harezmlilerin bir kısmı Selçuklu hizmetine girmeden evvel Van Gölü çevresinde bulunmaktaydı. ${ }^{11}$ ibn Bibi, başta Kayır Han olmak üzere Harezmli beylerin yanında 4000 süvarinin bulunduğu kaydederken, ${ }^{12}$ Ebu'l Farac 10.000 kişilik bir gruptan bahsetmektedir. ${ }^{13}$ Sayıları 25.000 kişiye kadar çıkarılan bu Harezmliler, ${ }^{14}$ Selçuklu ülkesinde belirli bölgelerde iktalar verilerek yerleştirileceklerdir. ${ }^{15}$

Celaleddin Harezmşah'ın ordusunda bulunan Kanglıların bir kısmının da Ahlat ve Meyyafarikin Eyyubileri tarafından orduya

D’ohsson, Moğol Tarihi, İstanbul 2006, s.91; M. Fuad Köprülü, "Harizmşahlar", iA V, S.271.

${ }^{10}$ Dağılan bu Harezmlilerin bir kısmı Trabzon taraflarına kaçtı. Bunlardan pek çoğu uçurumlardan aşağıya düşerek öldü. [Bkz. A. Taneri, Celalu'd-din Harizmşah ve Zamanı, Ankara 1977, s.72.] Nesevi, Kıpçakların Harezmşah ailesine sadık olduklarını, Celaleddin Harzemşah'ın Isfahan Kalesi önündeki yenilgisi üzerine Irak'dan dönüşü sırasında Kıpçaklardan talep ettiği yardımın sevinçle karşılandığını ve Kıpçakların derhal 50000 çadırlık bir kuvveti Sultan'ın yardımına göndermiş olduğunu belirtmektedir. Bkz. en-Nesevi, Siretü's-Sultan Celaleddin Mengüberti, (nşr. O. Houdas), Paris 1891, s.286vd; en-Nesevi, s.109; Z. Velidi Togan, "Azerbaycan", IA II, s.102.

${ }^{11}$ Bkz. İbn Bibi, El-Evamirü'l-Ala'iyye fi'l-Umuri'l Ala'iyye, (nşr. Mürsel Öztürk), Ankara 2014, s.419vd; Selçukname, s.137.

12 Bkz. İbn Bibi, a.g.e, s.422; , Selçukname, (nşr. M. Halil Yinanç), İstanbul 2007, s.139; Yazıcızade Ali, Tevarih-i Ali Selçuk, (nşr. Abdullah Bakır), İstanbul 2009, s.591; Müneccimbaşı Ahmed b. Lütfullah, Camiü'd- Düvel II, (nşr. Ali Öngül), İzmir 2000, s.73. 13 Gregory Ebu'l Faraç, Ebu'l Faraç Tarihi II, (Türkçe nşr. Ömer Rıza Doğrul), Ankara 1999, s.530.

14 Bu konu için bkz. M. Fuat Köprülü, a.g.m, s.292; Ali Sevim-Yaşar Yücel, Türkiye Tarihi, Selçuklu ve Beylikler Dönemi, Ankara 1989, s.162; O. Turan, Selçuklular Zamanında Türkiye, İstanbul 2010, s.399; O. Turan, Doğu Anadolu Türk Devletleri Tarihi, İstanbul 2009, s.200; F. Sümer, a.g.m, s.5; A. Sevim-E. Merçil, Selçuklu Devletleri Tarihi, Ankara 1995, s.465.

15 Bkz. el-Evamirü'l-Ala'iyye, s.423vd; Selçukname, s.140. Ayrıca bkz. O. Turan, Selçuklular Zamanında Türkiye, s.399; i.H. Uzunçarşılı, Osmanlı Devlet Teşkilatına Methal, Ankara 1998, s.114; N. Kaymaz, Anadolu Selçuklularının Inhitatında Idare Mekanizmasının Rolü, Ankara 2011, s.85vd. Moğollar önünden kaçarak Anadolu'ya gelen bu Harezmli Türkler Anadolu kültürünün de gelişmesine sebep olmuştur. Türk kültürü üzerinde etkili olan bu gelişme daha sonra Moğollara da tesir edecektir. Örneğin bazı et yemeklerinin Anadolu'ya gelişi bunların en önemlilerindendir. Büryan kebabı, külleme, yemeklere katılan güneşte kurutulmuş çiğ koyun kuyruğu gibi. Bkz., Bahaeddin Ögel, Türk Kültür Tarihine Giriş IV, Ankara 1987, s. 331, 373vd, 380.

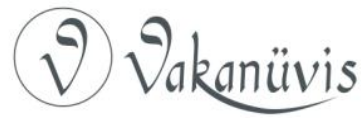


alındıkları ifade edilmektedir. ${ }^{16}$ Bunların Doğu Anadolu'da ve bilhassa Van Gölü Havzası'nda yerleşip yerleşmedikleri hakkında kesin bir bilgi bulunmamakla birlikte ${ }^{17}$ bahsi geçen Harzemli askerlerin bir bölümünün Haleb emiri Melik Nasır'ın hizmetine girerek, Urfa ve Harran şehirlerini ikta olarak aldıkları da kaydedilmektedir. ${ }^{18}$ Diğer taraftan Olcaytu Han zamanında Diyarbekir eyaletinin valiliği görevini yürüten II Basmış ${ }^{19}$ ve Anadolu'da tümen beyi olarak görev yapmış olan Körbuğa adlı idarecinin Kıpçak Türklerinden olması ${ }^{20}$ ve yöredeki bazı Kıpçak oymaklarının adlarını taşıyan yerleşim yerlerinin bulunması ${ }^{21}$ bölgede bir Kıpçak nüfusunun iskân edilmiş olduğunu göstermektedir. ${ }^{22}$

16 Bkz. C. Cahen, Osmanlılardan Önce Anadolu'da Türkler, (nşr. Y. Moran), İstanbul 1984, s.139; O. Yorulmaz, Geçmişten Günümüze Kanglı Türkleri, İstanbul 2012.s.125.

${ }^{17}$ Osmanlı arşiv belgelerinde Harzem, Havazim, Havazin, Horzum, Horzum Kebir adlarını taşıyan gerek Anadolu'da ve gerekse Arap vilayetlerinde pek çok aşiret mevcuttur. [Bkz. Cevdet Türkay, Başbakanlık Arşivi Belgelerine Göre Osmanlı Imparatorluğunda Oymak, Aşiret ve Cemaatler, İstanbul 1979, s.88, 90; Yusuf Halaçoğlu, Anadolu'da Aşiretler, Cemaatler, Oymaklar (1453-1650) I-IV, Ankara 2009, s.264, 277, 274, 319, 343, 363, 414, 558, 631, 633, 1041, 1042, 1066, 1067, 1090, 1093, 1310, 1349, 1463, 1478, 1532, 1610, 1611, 1637, 1685, 1689, 1746, 1759, 1895, 1899, 1900.] Ayrıca bkz., Osman Yorulmaz, Geçmişten Günümüze Kanglı Türkleri, 133139.

${ }^{18}$ Bkz. Ebu'I Faraç Tarihi II, s.537.

${ }^{19}$ Ebu'l Kasım Abdullah b. Muhammed Kaşani, Tarih-i Olcaytu, (nşr. M. Hemblu), Tahran 1348, s.9; Z. Velidi Togan, Umumi Türk Tarihi, s.253.

${ }^{20}$ Kerimüddin Mahmud-i Aksarayi, Müsameretü'l-Ahbar, (nşr. Mürsel Öztürk), Ankara 2000, s.144; Camiü't Tevarih (ilhanlılar kısmı), (nşr. İsmail Aka, Mehmet Ersan ve Ahmad Hisamipour Khelejani), Ankara 2013, 76.256.279; Z. Velidi Togan, a.g.e, s.244.

${ }^{21} \mathrm{Bu}$ yer adları hakkında geniş bilgi için bkz. İbrahim Gürdal, Köylerimiz (1968'e kadar), (İçişleri Bakanlığı Başbakanlık Basımevi), Ankara 1968, s.15,56,164,286,374; Mehmet Eröz, "Sosyolojik Yönden Türk Yer Adları", Türk Yer Adları Sempozyumu Bildirileri (11-13 Eylül 1984), Ankara 1984, s. 40,46; H. Nihal- Ahmet Naci, "Anadolu'da Türklere Aid Yer İsimleri", Türkiyat Mecmuası II, İstanbul 1928, s.258. Ayrıca Kotandüzü (Erzurum-Pasinler), A. Kotanlı, Y. Kotanlı (Selim-Kars), Kotancı (Diyadin-Ağrı) gibi yer isimleri de Kıpçak Türklerinin bölgedeki izleri olarak karşımıza çıkmaktadır. [Bkz. İsmail Kayabalı vd., Beş Nehir (Çoruh, Kür, Aras, Dicle, Fırat) Boyunun Türklüğü, Ankara 2013, s.427; M. Fahrettin Kırzıoğlu, Yukarı Kür ve Çoruk Boyları'nda Kıpçaklar, s.92.105.136; L. N. Lezina-A. V. Superanskaya, Türk Onomastikası (Bütün Türk Halkları), İstanbul 2009, s.370; Mehmet Kıldıroğlu, Kırgızlar ve Kıpçaklar, Ankara 2013, s.310.] Osmanlı arşiv belgelerinde Kotan/Kotanlı/Kotanlu cemaati, Rakka Eyaleti içerisinde ve Yörük olarak gösterilmektedir. [Bkz. Cevdet Türkay, s.535.] Osmanlı arşiv belgelerinde Kamar

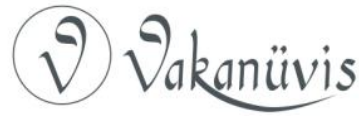


Celaleddin Harezmşah'ın ordusunun önünden ve arkasından gelen kalabalık bu Türkmenler Anadolu'ya bir sel gibi akmaya başladılar. Cüveyni Celaleddin'in Ahlat'ı kuşatmasından evvel şehri savunanların bölgeye çok sayıda Doğu bölgelerinden getirdikleri Türk ve Türkmen gruplarını yığarak müdafa etmeyi düşündüklerini belirtmektedir $\mathrm{ki}^{23}$ Harzemşahların hakimiyeti zamanında Ahlat ve civarında kalabalık bir Avşar aşiretinin bulunduğu ve Celaleddin Harzemşah'ın bunlardan 30000 koyunu ganimet olarak aldığı belirtilmektedir. ${ }^{24}$ Yıne aynı dönemde Urmiye ve havalisini yurt tutmuş, 10000 kişilik askeri kuvvet çıkarabilecek bir Yıva topluluğu vardı. ${ }^{25}$ Bunların bölgede asayişi bozucu faaliyetleri ${ }^{26}$ Celaleddin Harezmşah tarafından dağıtılmalarına sebep olmuştu. ${ }^{27}$ Yıvalar bu hadiseden bir süre sonra Moğol askeri birliklerinin bölgeyi işgali üzerine Doğu Anadolu'ya çekilecektir. ${ }^{28} \mathrm{Bu}$ bağlamda XVI. yüzyıla ait Osmanlı arşiv belgelerinde Malazgirt ve Hınıs sancaklarına bağlı Yıva Viranı ve Yıvaclu adlı köyler tespit edilmektedir

Uşağı adıyla Rakka Sancağı'nda, Komarlar, Komarlı adıyla da Lapseki ve Sinop Sancaklarında ve Kumarlı, Kumarlu adıyla da Çatalca Kazası'nda birer Türkmen taifesi mevcuttur. Bkz., Cevdet Türkay, a.g.e, s.31, 111, 533.

22 Olcaytu zamanının önemli taraflarından biri de bu dönemde Türk asıllı emirlerin ön plana çıkarılmasıdır. Bu konuda ayrıntılı bilgi için [bkz. F. Sümer, "Anadolu'da Moğollar", s.21vd.] Diyarbakır yöresinde isimleri değiştirilmiş Kıpçak/Kuman oymaklarına ait yer isimleri vardır. Gomaniayınbirlik (Çökeksu), Çinezur (Çağdaş), Terbile/Terbule (Kırmatepe), Kulfa (Yüksek) vb. Geniş bilgi için bkz. Mehmet Eröz, "Sosyolojik Yönden Türk Yer Adları", Türk Tarihi Dergisi, Sayı:12, (Şubat1986) s.40vd.

${ }^{23}$ Cüveyni II, s.367vd; O. Turan, Doğu Anadolu Türk Devletleri Tarihi, s.147.

24 Z. Velidi Togan, "Azerbaycan", s.101.

25 Hamdullah Kazvini, Hoy şehrinden "Iran'ın Türk Ülkesi" diye bahsetmektedir. Nuzhet-Al- Qulub, s.86vd; Z. Velidi Togan, Umumi Türk Tarihine Giriş, s.254. Yıvalar hakkında geniş bilgi için bkz. F. Sümer, "Yıva Oğuz Boyuna Dair", Türkiyat Mecmuası IX, İstanbul 1951, s.151-166; V. Minorsky, Studies in Caucasian History (The Shaddadis of Ani), London 1953, s.152.

${ }^{26}$ Bkz. en-Nesevi, (O. Houdas), s.208vd; en-Nesevi, s.78; İbnü'l Esir, El-Kamil fi't Tarih XII , (nşr. Abdulkerim Özaydın), İstanbul 1987, s.313; O. Turan, a.g.e, s.388.

${ }^{27}$ Bkz. en-Nesevi, (O. Houds), s.243,306-308; en-Nesevi, s.78vd; F. Sümer, Oğuzlar (Türkmenler), Tarihleri, Boy Teşkilatı, Destanları, İstanbul 1999, s.352vd; A. Taneri, a.g.e, s.44; Z. Velidi Togan, a.g.m, s.101.

28 F. Sümer, Oğuzlar (Türkmenler), s.352vd.

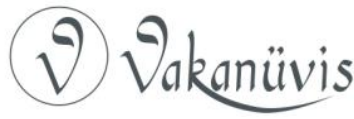


$\mathrm{ki}^{29}$ bu kayıt bölgede yerleşmiş ya da belli bir dönem yurt tutmuş Yıva Türkmenlerinin varlığını işaret etmektedir.

Azerbaycan'a gelen Moğol tümenleri otu bol ve aynı zamanda kışlamak için uygun olan Arran ve Mugan'da karargâh kurdular. ${ }^{30}$ Moğolların bölgeyi işgali üzerine Selçuklular döneminden beri bölgede oturan Türkmenler Anadolu'ya ve özellikle de Doğu Anadolu'ya göç etmek zorunda kaldılar. ${ }^{31}$ Batı yönünde hareket eden bu Türkmen kitleleri Aras vadisini takip ederek Sürmeli, Eleşgirt ve Ahlat'a kadar ilerlemişlerdir. Azerbaycan'dan Anadolu'ya yönelen Türkmen göçü devrin kaynaklarına da yansımıştır. Nitekim Nesevi; "Türkmenlerin Azerbaycan'da, Karabağ ovalarında çekirgeler gibi kaynaştığın Şarktan Garba doğru bu insan selinin Aras üzerindeki köprüleri kapattığını ve bu izdiham dolayısıla geçemediklerini" anlatır. ${ }^{32}$ Aynı zamanda Moğollar da askeri birliklerini teşkil eden Moğol ve Türk aşiretlerini sürüleriyle birlikte Anadolu'nun doğu bölgelerine yerleştirmişlerdir. ${ }^{33}$ $\mathrm{Bu}$ yöredeki yer adlarından ${ }^{34}$ ve mezartaşları üzerindeki tamgalardan anlaşılmaktadır. ${ }^{35}$ Özellikle İlhanlı dönemi eserleri üzerindeki bitki ve hayvan üslubunun ${ }^{36}$ bölgeye Moğollarla birlikte gelen Uygur Türkleri tarafından getirilmiş olabileceği kuvvetle muhtemel görünmektedir. Bu

${ }^{29}$ Tuncer Baykara, Hınıs ve Malazgirt Sancakları Yer Adları (XVI. yy), Ankara 1991, s.42.

${ }^{30}$ F. Sümer, "Anadolu'da Moğollar", s.2vd.

31 F. Sümer, Oğuzlar, s.155, 353; A. Yaşar Ocak, a.g.e, s.37.

${ }^{32}$ en-Nesevi, (O. Houdas), s.370vd; en-Nesevi, s.142; O. Turan, Selçuklular Zamanında Türkiye, 524.

${ }^{33}$ Geniş bilgi için bkz., M. Fuad Köprülü, a.g.e, s.91vd.

${ }^{34}$ Bkz. M. Fuad Köprülü, a.g.e, s.92vd; C. Cahen, a.g.e, s.306. Bu konuda geniş bilgi için bkz. F. Sümer, Oğuzlar, s.177vd. Ayrıca XVI. yüzyılda Anadolu'da Oğuz boylarına ait yer adları için bkz. F. Sümer, Oğuzlar, s.405-427.

${ }^{35}$ Bkz. M. Fuad Köprülü, a.g.e, s.92; C. Cahen, Osmanlılardan Önce Anadolu, s.308. Bu işaretler için bkz. İ. Kafesoğlu, "Ahlat ve Çevresinde 1945'te Yapılan Tarihi ve Arkeolojik Tetkik Seyahat Raporu”, iÜEF Tarih Dergisi I/1-2, İstanbul 1944, s. 199; Recep Yaşa, Bitlis'te Türk Iskanı (XII. ve XIII. Yüzyıl), Ankara 1992, s.170.

${ }^{36}$ Türklerde hayvan ve bitki üslubunun sanata yansımaları konusunda bkz. Nejat Diyabekirli, Hun Sanatı, İstanbul 1972, s.116. Ayrıca bkz. L. Rasonyi, Tarihte Türklük, Ankara 1996, s.43vd; Abdulhaluk Çay, Anadolu'da Türk Damgası (Koç-koyun HeykelMezartaşları ve Türklerde Koç-Koyun Meselesi), Ankara 1983, s.9vd; Yaşar Kalafat, Doğu Anadolu'da Eski Türk Inançlarının Izleri, Ankara 1999, s.126vd; Yaşar Çoruhlu, Türk Sanatında Hayvan Sembolizmi- I, İstanbul 1995, s.73-92.

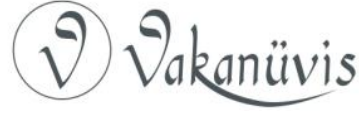


Uygurlar arasında devletin üst kademelerine kadar yükselmiş olanlar da vardır. İlhanlı devletinin hizmetinde, bilhassa Olcaytu döneminde Uygur asıllı bey ve komutan olduğu bilinmektedir. ${ }^{37}$ Nitekim Ahlat'ta kümbetleri bulunan ve kitabesinde 1281 yılında öldüğü anlaşılan ve kendisinden "Emirü'l Kebir" olarak bahsedilen Bugatay Aka ile Şirin Hatun'un Uygur asıllı oldukları kuvvetle muhtemeldir. ${ }^{38}$

Van Gölü Havzası'nda yoğunlaşan bu Türkmen nüfusu, Eyyubiler idaresinin Van Gölü Havzası'nı ihmal edişi ve bu arada Celaleddin Harezmşah'ın faaliyetleri ile Moğol birliklerinin yağma ve katliamlarının bölgede meydana getirdiği istikrarsızlık ${ }^{39}$ yöre insanının çevreye dağılmasına sebep olmuştur. Moğol ordularının önünden kaçan Türkmen boy ve oymakları Aras vadileri, Van Gölü Havzası, Muş ve Doğu Anadolu'nun pek çok yerlerini kendilerine yurt edinmişlerdi. ${ }^{40}$

Bölgenin sürekli savaş alanı haline gelişi ise bölgedeki nüfusun çevreye dağılmasına sebep olmuştur. Buna daha sonraki dönemde Tebriz'e ödenen vergiler ile her geçen gün sayıları artan İlhanlı sivil ve askeri memurlarının ağır masrafları ile ödenen rüşvetlerde eklenince Doğu ve Güneydoğu Anadolu'daki yerleşik Türk nüfus Orta ve Batı Anadolu'ya çekilmiştir. ${ }^{41}$ İbn Bibi'nin ifadelerine göre, Ahlat, Malazgirt,

37 Bkz. Tarih-i Olcaytu, s.9,49; Peter b. Golden, a.g.e, s.317; F. Sümer, "Anadolu'da Moğollar", s.15-24; F. Sümer, "Ahlat Şehri ve Ahlatşahlar", Belleten, L/297 (1986), s.459; F. Sümer, "Eski Türk Devletlerinde Ağa Ünvanı", Türk Dünyası Araştırmaları, Sayı: 38, İstanbul (Ekim) 1985, s.58-66; Recep Yaşa, a.g.e, s.57.

38 Bkz. A.Şerif Beygu, Ahlat Kitabeleri, İstanbul 1932, s.72vd; N. Tabak, Ahlat Türk Mimarisi, İstanbul 1972, s.12. H. Karamağralı, "Büyük Bir Kültür ve Sanat Merkezi Olan Ahlat", Türkler, Ankara 2002, s.149; F. Sümer, "Anadolu'da Moğollar", s.459; Recep Yaşa, a.g.e, s.57. Moğollarla gelen Uygur Türklerinin İlhanlılar ve daha sonraki dönemde Anadolu'da meydana gelen olaylarda önemli roller üstlendikleri görülmektedir. Bunlardan özellikle tümen beyleri olan Tarımtaz, Senektay, Ertene (Ertana) kardeşler önemlidir. [Bkz. Z. Velidi Togan, a.g.e, s.244.] Eratna'nın soyu ve ailesi hakkında geniş bilgi için bkz. Kemal Göde, Eratnalılar (1321-1387), Ankara 2000, s.25vd.

${ }^{39}$ O. Turan, Selçuklular Zamanında Türkiye, s.395.

40 O. Turan, Doğu Anadolu Türk Devletleri Tarihi, s.147.

41 Bkz. F. Sümer, "Anadolu'da Moğollar ve Ağaç-eriler", Belleten XXVI, s.521-528; A. Yuvalı, "Ilhanlıların Anadolu Politikası ve Doğu Anadolu Şehirlerinin Vergi Potansiyeli", XI. Türk Tarih Kongresi II, (5-9 Eylül 1990), Ankara 1994, s.600.

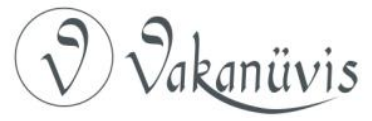


Bargiri ve Eleşkirt şehirlerinin artık akbabaların ve diğer yırtıcı kuşların yuva yaptığı, insanoğlundan dolaşan kimsenin kalmadığı bir yer haline gelmişti. ${ }^{42}$ Aynı şekilde Neşri, 170 yıl Ahlat'ta kalan Osman Bey'in dedesi Süleyman Şah liderliğindeki Kayıların Moğol baskısından dolayı göç ettiğini kaydetmektedir. ${ }^{43}$ Yine Şerefname'de ve Evliya Çelebi Seyahatnamesi'nde Seyyid Hüseyin Ahlati'nin Moğol tehlikesinden dolayı etrafındaki çok kalabalık bir grupla (12000 kişi) Mısır'a iltica ettiğinden bahsedilmektedir. ${ }^{44}$ Ermeni müverrih Vardan, "Hülegü’nün bölgeye gelişi üzerine korku içinde olan ahali bizim ülkenin yukarı kısmını terk etti." diyerek bu hakikati dile getirmektedir. ${ }^{45}$

Bölgeye esas büyük nüfusun gelişi Hülegü'nün Batı seferi sonucunda olmuştur. Hülegü'nün emrindeki askeri güç Kağan'ın ordusunun küçük bir numunesi görünümündeydi. Zira Mengü Kağan kardeşi Hülegü’yü İran'a gönderirken bütün Moğol ordusunun \% 20 sinin verilmesini emretmişti. ${ }^{46} \mathrm{Bu}$ da 280000 gibi büyük bir rakama tekabül etmekteydi. Her bir asker ailesiyle geldiğine göre ortalama bir hesapla Hülegü'nün yanında bir ile bir buçuk milyon civarında büyük bir nüfus mevcuttu. ${ }^{47}$ Teşkil edilen orduda Çingiz Han devrindeki kumandanların oğulları ile hanedanın diğer üyelerini temsilen şehzadeler de vardı. ${ }^{48}$ Moğolca konuşan toplulukların hemen hepsinden beğler bulunmakla birlikte bunlar içerisinde özellikle Suldus $^{49}$ ve Celayirli ${ }^{50}$ oymaklarına mensup olanlar ağır basıyordu. ${ }^{51}$

${ }^{42}$ Bkz. el-Evamirü'l-Ala'iyye, s.416; El-Kamil fi't Tarih XII, s.454.

43 Bkz. Mehmet Neşri, Kitab-ı Cihannüma I, (nşr. F. Reşit Unat-M. Altay Köymen), Ankara 1987, s.57vd; el-Evamirü'l-Ala'iyye, s.405.

44 Bkz. Şerfhan Bitlisi, Şerefname, (nşr. M. Emin Bozarslan), İstanbul 1990, s.404; Evliya Çelebi, Seyahatname I/4, (S. Ali Kahraman-Yücel Dağlı), İstanbul 2010, s. 189.

45 Bkz. Müverrih Vardan, s.230; Hasan Oktay, Ermeni Kaynaklarında Türkler ve Moğollar, İstanbul 2007, s.173vd.

${ }^{46}$ Ebu'l Farac Tarihi II, s.556; İbnü'l-ibri Ebu'l- Ferec, Tarih-i Muhtasari'd-Düvel, (nşr. Şerafeddin Yaltkaya), Ankara 2011, s.25vd.

47 Z. Velidi Togan, a.g.e, s. 251.

${ }^{48}$ Hülegü’nün ordusu batıya gönderilirken her şey düşünülmüştü. Kale kuşatmalarında kullanılacak silahlardan, bunları kullanacak birlikler, ordunun ihtiyacı olan otlaklar, nehirler üzerindeki köprüler ve askerin iaşesinin nasıl tedarik edileceği vs. Camiü't Tevarih, 13vd; Cüveyni III, s.488vd.

${ }^{49}$ Çingiz Han'ın hükümdar olduktan hemen sonra bu kabileye mensup kişileri önemli devlet görevlerine getirdiği bilinmektedir. [Bkz. Moğolların Gizli Tarihi, (nşr. Ahmet

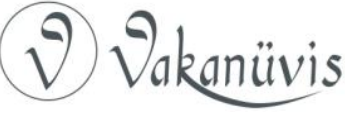


Bunlar İlhanlı ordusu içerisinde birkaç tümeni teşkil etmekteydiler. ${ }^{52} \mathrm{Bu}$ oymaklara mensup beyler Hülegü döneminden devletin yıkılışına kadar sivil ve askeri bürokraside önemli roller üstleneceklerdir. Hülegü’nün ordusunda kalabalık bir Uyrat grubu vardı ki bunlar özellikle Doğu ve Güneydoğu Anadolu'da yerleşmiş ve bölgenin etnik ve sosyal yapısı üzerinde etkili oldukları gibi siyasi meselelerde de ön plana çıktıkları görülmektedir. ${ }^{53}$ Bunların dışında Tatarlar, Kireyitler, Naymanlar gibi topluluklar ile ${ }^{54}$ Sünit, Bisüvüt, Suganut, Mangıt, Kurulas, Kongırat, Dürben, Kıyat Bayaut, Barın gibi uruğlar da mevcuttu. ${ }^{55}$

Hülegü Azerbaycan'a geldiğinde Mugan ve Arran otlaklarının ordusu için ne kadar önemli olduğunu görmüştü. Mahiyetinde bulunan büyük orduyu ancak bu bölge barındırabilirdi. Özellikle Aladağlar sadece İlhanlı hükümdar ve ailelerinin değil aynı zamanda çok sayıda Türk ve Moğol kabileleri için de uygun bir yaylak olabilirdi. Çünkü bu geniş yaylalar av sahaları ve gür otlaklarıyla Türkistan'ın özelliklerine sahipti. Diğer taraftan Aladağlar, Doğu Anadolu'yu İran ve Azerbaycan'a bağlayan stratejik bir konuma sahipti. Bu yüzden Hülegü

Temir), Ankara 2010, s.33.] İlhanlı Devleti'nin kurulmasıyla Sulduslar da diğer Moğol kabileleri gibi Anadolu'ya gelerek yerleşmişlerdir. Bu konu hakkında geniş bilgi için bkz., I. Hakkı Uzunçarşılı, "Emir Çoban Soldoz ve Demirtaş", Belleten XXXI/124, s.601vd; Ahmet Temir, "Sulduz/Suldus", IA XI, s.9vd.

${ }^{50}$ Celayirliler, Cengiz Han'ın tarih sahnesine çıktığı ilk zamanlardan itibaren onunla birlikte hareket etmişler ve kalabalık bir orduyla Cengiz Han'ın seferlerine katılmışlardır. Bkz., Moğolların Gizli Tarihi, s.66, 84, 87, 138. Celayirler hakkında geniş bilgi için bkz., M.Halil Yinanç, "Celayir", IA III, s.64vd; Muzaffer Ürekli, "Celayirliler", DiA VII, s.264vd.

${ }^{51}$ F. Sümer, "Anadolu'da Moğollar", s.11.

52 Z. Velidi Togan, a.g.e, s 252.

${ }^{53}$ Bkz. Hafız-ı Ebru, Chroniqe des Rois Mongols en Iran, (Zeyl-i Camiü't-Tevarih Reşidi Zübdetü't-Tevarih), (nşr. K. Bayani), Paris 1936, s.119; Kemalu'd-din Abdürrezzak Semerkandi, Matlau's-Sadeyn Mecmua-ı Bahreyn I, (nşr. Abdu'l Hüseyin Nevani), Tahran 1353, s.130vd.

${ }^{54}$ Hülegü'nün mahiyetinde bulunan bu kabileler hakkında bilgi için bkz. F. Sümer, "Anadolu'da Moğollar", s.11vd.

${ }^{55}$ Z. Velidi Togan, a.g.e, s.252vd. Bu Moğol boylarının bazıları Anadolu'nun orta ve batı taraflarına yerleştirildiler. Bkz. M. Fuad Köprülü, a.g.e , s.43.

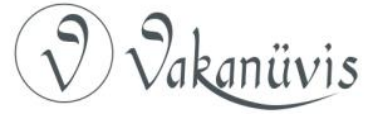


hiç tereddüt etmeden Baycu Noyan'ı komuta ettiği orduyla birlikte Anadolu'ya göndermişti. ${ }^{56}$

Bu kabileler haziran ya da temmuz başından ekim ya da kasım aylarına kadar sürüleriyle burada kalırlardı. Bu dönemlerde bölgeden geçen Marco Polo, bölgenin en büyük şehirleri arasında Erciş’i göstererek Tatar ordularının tamamının burada kaldığını belirtmektedir. Geniş otlaklara sahip olan bölgenin, büyük hayvan sürülerine sahip Tatarlar için yaylak vazifesi gördüğünü, kış mevsiminde ise daha sıcak olan yerlere göç ettiklerini dile getirmektedir. Aladağlardan bahsederken de karla kaplı olduklarını, yazın eriyen karın yamaçlarda bol otlakları oluşturduğunu ve çevreden büyük koyun sürülerinin burada beslendiğini belirtmektedir. ${ }^{57}$ Aynı şekilde XIV. yüzyılda sözü edilen yöreden bahseden Ebu'I-Fida mera ve çayırların geniş yer kapladığına dikkat çekmiş ve bölgenin Tatar kabilelerine konaklık vazifesi gördüğünü kaydeder. ${ }^{58}$ Nitekim yörenin toponomisi de bu gerçeği ortaya koymaktadır. Malazgirt'e bağlı Tatar Gazi $^{59}$ ve Tatar Düzü, Tatar Yazısı, ${ }^{60}$ Ahlat'ta bağlı Tatar Gazi Köyü ${ }^{61}$ ile Tatarcık Mezrası ${ }^{62}$ yer adları varlıklarını halen devam ettirmektedirler.

Aladağları yazlık karargâh olarak tesis eden Hülegü, ${ }^{63}$ illhanlılar Doğu ve Güneydoğu Anadolu'yu Hülegü Han'dan itibaren iki eyalet halinde yönetmişlerdir. Nitekim Moğolların ülkeyi eyaletlere ayırırken yöredeki geçerli ananeyi de dikkate almaktaydılar. Buna göre umumiyetle tabii hudutlar bu taksimatta belirleyici olmuştur. Ayrıca

${ }^{56}$ Gürsoy Solmaz, Ermeni Müverrihlerine Göre Moğollar ( Müverrih Kiragos'tan Alınmıştır), (Edvar Dulaurier Tercümesinden), Erzurum 2000, s.95.

${ }^{57}$ Bkz. Marco Polo, Dünyanın Hikâye Edilişi, (nşr., Işık Ergüden), İstanbul 2003.s.77vd.

${ }^{58}$ Bkz. Ebu'l-Fida, Takvimü'l-Büldan, (nşr. Ramazan Şeşen), İstanbul 2017, s.324.

${ }^{59}$ Bkz. Ibrahim Gürdal, a.g.e, s.505; Mehmet Eröz, Doğu Anadolu'nun Türklüğü, İstanbul 1982, s.169; İsmail Kayabalı vd. a.g.e, s.402; F. Sümer, "Anadolu'da Moğollar", s.143.

${ }^{60}$ F. Sümer, "Anadolu'da Moğollar", s.143.

${ }^{61}$ H. Nihal- Ahmet Naci, a.g.m, s.257.

${ }^{62}$ Orhan Kılıç, XVI. Yüzyılda Adilcevaz ve Ahlat (1534-1605), Ankara 1999, s.33vd.

$63 \mathrm{Bu}$ konuda geniş bilgi için bkz. Neslihan Durak, "illhanlılar Döneminde Aladağ ve Çevresi", I. Uluslararası Ahlat-Avrasya Bilim, Kültür ve Sanat Sempozyumu (23-25 Ağustos 2012), İstanbul 2013, s.242-249.

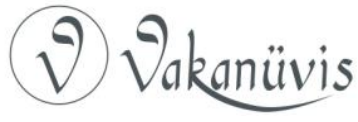


Moğollar askerliği ve iaşe teşkilatını da göz önünde bulundurmuşlardır. Özellikle konargöçer toplulukların yaylak ve kışlaklarının bir idari ünitede birleştirilmesine önem vermişlerdir. ${ }^{64}$ Sözü edilen eyaletlerden biri merkezi Musul olan Diyarbekir eyaleti, diğeri ise merkezi Ahlat olan Van eyaleti idi. ${ }^{65}$ Moğollar Van Gölü'nün kuzeybatısında yer alan ve Van Eyaleti'nin merkezi olan Ahlat şehrinde, muhtemelen içerisinde Türklerin de bulunduğu "Ahlat Tümeni" olarak da bilinen 10000 kişilik bir askeri kuvvet bulunduruyorlardı.

Van Eyaleti gerek askeri ve ulaşım imkânları ve gerekse buradaki Türk ve Moğol topluluklarının sosyo- ekonomik hayat şartlarından dolayı kuzey-güney istikametini etkin bir şekilde kullanmak durumundaydılar. Bu topluluklar Erzurum- Muş- Ahlat- Aladağ hattından güneyde Musul'a kadar uzanan bölgede mevsimsel olarak

64 Diyarbekir da bulunan Moğol askeri birliği genellikle Uyratlardan oluşmaktaydı. Bunlar kışı Musul ve civarında geçirirken yaz aylarında ise Erzurum, Muş, Bingöl havalisindeki yaylaları kullanıyorlardı. Dolayısıyla Doğu ve Güneydoğu Anadolu'nun büyük bir kesimi bu eyaletin sınırları içerisindeydi. Merkezi Ahlat olan Van Eyaleti ise gerek askeri ve ulaşım şartları ve gerekse buradaki Türk ve Moğol toplulukları sosyoekonomik hayat şartlarından dolayı kuzey-güney istikametini etkin bir şekilde kullanmak durumundaydılar. Bu topluluklar Erzurum- Muş- Ahlat- Aladağ hattından güneyde Musul'a kadar uzanan bölgede mevsimsel olarak hareket halindeydiler. Bunun neticesinde sözü edilen güzergâh bir idari teşkilat içerisinde toplanmıştı. [Bkz. Muammer Gül, "Ilhanlılar Döneminde Diyarbakır", I. Uluslararası Oğuzlardan Osmanlı'ya Diyarbakır Sempozyumu ( 20-22 Mayıs 2004 Diyarbakır ), Diyarbakır 2004, s.195vd.] ilhanlılarda eyaletler ve bunların idaresi hakkında geniş bilgi için bkz., B. Spuler, İran Moğolları(Siyaset, Idare ve Kültür IIhanlılar Devri), (nşr. Cemal Köprülü), Ankara 2011 s.367vd; Bkz. İ. Hakkı Uzunçarşılı, Osmanlı Devlet Teşkilatına Methal, Ankara 1998, s.254-261.

${ }^{65}$ Bkz. F. Sümer, Kara Koyunlular, Ankara 1992, s.33. Ayrıca bkz. F. Sümer, "Anadolu'da Moğollar", s.100vd; F. Sümer, "Ahlat Şehri ve Ahlatşahlar", s.46; B. Spuler, a,g,e, s.384, 385; İsmail Aka, "Anadolu'dan Iran'a Göçler", Tarihten Günümüze Türk-İran İlişkileri Sempozyumu (16-17 Aralık 2002 Konya), Ankara 2003, s.57; Şevket Beysanoğlu, Anıtları ve Kitabeleri ile Diyarbekir Tarihi I, Ankara 1987, s.371-375. Van Eyaleti Erzurum'dan Salmas'a, Arran'dan Ahlat'a kadar olan bölgeyi kapsamaktaydı. Bkz Hamd-Allah Mustawfi Kazwini, Nuzhat- Al- Qulub, (nşr. G.Le Strange), London 1915, s.100.

${ }^{66}$ Bkz. Nuzhat- $A$ l- Qulub, s.100.

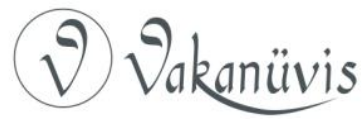


hareket halindeydiler. ${ }^{67}$ Hülegü'nün batıya gönderilişi sırasında beraberinde kalabalık bir Uyrat topluluğunun da bulunduğu bilinmektedir. Pek çok Türk ve Moğol kabileleri ile birlikte batıya gelen bu Uyratlar Anadolu'nun özellikle Doğu ve Güneydoğusu ile Irak'ın kuzeyinde yoğun bir şekilde yerleştikleri görülmektedir. ${ }^{68}$

Baycu'nun komuta ettiği ordunun aileleriyle birlikte Anadolu'ya yerleşmesi, Hülegü döneminde diğer Moğol kuvvetlerinin de bunlara katılmaları Doğu ve Güneydoğu Anadolu'da yurt tutmuş Türkmen gruplarının göç etmesine sebep olmuştur. Bu Türkmen taifeleri Anadolu'nun kıyı bölgelerine ${ }^{69}$ ya da Bizans sınırına sığınırken diğer bölümü de Memlûk topraklarına göç etmiştir. Nitekim İbn Şeddat, 1260 Ayn Calut Savaşı'nı müteakiben Anadolu'dan 40000 haneden daha fazla bir Türkmen topluluğunun Memlûklara iltica ettiğini belirtmektedir ki bunların büyük bir bölümü Uyratlardır. ${ }^{70}$ Sultan Baybars tarafından bu Türkmen taifesinin bir kısmı Memlûklu ordusuna alınırken diğer bir bölümü de Gazze'den Antakya'ya kadar olan sahaya iskân edilmiştir. ${ }^{71} \mathrm{Bu}$ durum daha sonra kurulacak olan Dulkadirli ve Ramazanoğulları beyliklerinin temellerini attığı gibi Orta

${ }^{67}$ Bkz. Muammer Gül, a.g.m, s.195vd. İlhanlılarda eyaletler ve bunların idaresi hakkında geniş bilgi için bkz., B. Spuler, a.g.e, s.367vd; Bkz. I. Hakkı Uzunçarşılı, a.g.e, s.254-261.

${ }^{68}$ Adıyaman ilinin Besni kazasına bağı Oyratlı Köyü bunun en önemli göstergesi durumundadır. [Bkz. brahim Gürdal, a.g.e, s.435; Mehmet Eröz, Doğu Anadolu'nun Türklüğü, s.196.] XVI. Asrın başlarına ait Osmanlı arşiv belgelerinde AdıyamanBesni'deki bu Oyratlu taifesi Beğdilli boyuna mensup gösterilmektedir. [Bkz. Yusuf Halaçoğlu, a.g.e IV, s.1517, 1634,1813.] Bugün Irak Türklerinin mani tarzındaki şiirlerine verilen "hoyrat" adı Uyrat (Oyrat)'dan gelmiş olmalıdır. Bkz. F. Sümer, "Anadolu'da Moğollar", s.139.

69 Bkz. İbrahim Tellioğlu, Osmanlı Hâkimiyetine kadar Doğu Karadeniz'de Türkler, Trabzon 2004, s.111vd; J. P. Fallmerayer, Trabzon Imparatorluğunun Tarihi, Ankara 2011, s.181vd; Murat Keçiş, Trabzon Rum Imparatorluğu ve Türkler (1204-1404), Ankara 2013, s.93vd. Doğu Karadeniz bölgesine yaylalardan, geçitlerden ve Harşit vadisinden inen Oğuz Çepni boyu Samsun'a kadar olan sahanın Türkleşmesini sağlamışlar ve Canik bölgesine adını veren Hırıstiyan Çan kavmi ise yok olmaya yüz tutmuştur. Gresun'a kadar gelen Türkmenler bölgede küçük beylikler dahi kurmuşlardır. Bkz., O. Turan, Selçuklu Tarihi ve Türk-Islam Medeniyeti, s.301.

${ }^{70}$ F. Sümer, "Anadolu'da Moğollar", s.27vd.

${ }^{71}$ Bkz. İbn Şeddad, Bay-bars Tarihi, (nşr. M. Şerafettin Yaltkaya), İstanbul 1941, s.155; Refet Yinanç, Dulkadir Beyliği, Ankara 1989, s.3; F. Sümer, Oğuzlar, s.179vd.

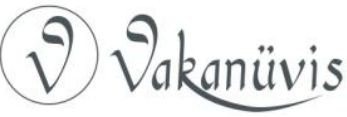


Anadolu ile Çukurova bölgelerinin Türkleşme sürecine katkı sağlayacaktır. ${ }^{72}$

Hülegü döneminde Erzurum-Bingöl-Muş yörelerini yaylak, Musul yöresini de kışlak olarak kullanan Uyratlar, zaman zaman da bölgede yağma hareketlerinde bulunuyorlardı. Bilhassa Erzurum ve çevresini yakıp yıkmışlardı. Gazan Han tarafından görevlendirilen Emir Mulay karşısında tutunamayan bu Uyratların bir kısmı Şam taraflarına kaçarak Memluklara iltica edeceklerdir. ${ }^{73}$ Geride kalanlar ise daha sonraki siyasi gelişmelerin içerisinde yer alarak adlarından sıkça söz ettireceklerdir. Nitekim Gazan Han ile Baydu arasındaki taht mücadeleleri sırasında Baydu'nun yanında yer alarak bunu göstermişlerdir. Taht mücadelesini Gazan Han'ın kazanması üzerine Uyratlar, Doğu Anadolu'yu boşaltarak güneye yani Memlûk topraklarına iltica etmişlerdir. ${ }^{74}$

Şam yöresine gelen ve 10.000 çadırdan müteşekkil oldukları anlaşılan Uyrat taifesinin başında Hülegü'nün kız kardeşinin kocası Targay/Turgay vardı. ${ }^{75}$ Yaşlı erkek, çocuk ve kadınlardan oluşan bu kalabalık Uyrat taifesinin yanında çok sayıda hayvan ve eşya da bulunmaktaydı. Memlûk Sultanı Ketbuga'nın Moğol kökenli oluşu Uyratların böyle bir tercih yapmalarında önemli rol oynamıştır. ${ }^{76}$ Uyratların Doğu ve Güneydoğu Anadolu'da kalan diğer oymakları bölgedeki varlıklarını XV. asrın başlarına kadar devam ettirmiştir. ${ }^{77}$ Nitekim bu Uyrat oymakları XIV. yüzyılın ortalarından itibaren Erciş şehri merkez olmak üzere Van Gölü Havzası'nda etkin hale gelmeye başlayan Kara Koyunlu Türkmen federasyonunun da içerisinde yer

\footnotetext{
${ }^{72}$ F. Sümer, "Anadolu'da Moğollar", s.45.

${ }^{73}$ Camiü't-Tevarih, s.254vd.

74 Reşidü'd-din Fazlullah Hemedani, Tarih-i Mübarek Gazani (Destan-i Gazani), (nşr. Karl Jahn), London 1940, s.97; İbni Tagrıberdi, En Nücumu'z-Zahire, (nşr. Ahsen Batur), İstanbul 2013, s.85; Ebu'l-Farac II, s.659; Cüneyt Kanat, " Gazan Han Zamanında Memluk Devletine iltica Eden Uyratlar", Tarih İncelemeleri Dergisi XV, İzmir 2000, s.108vd; M. Gül, a.g.e, s.183.

${ }^{75}$ En Nücumu'z-Zahire, s.85.

${ }^{76}$ En Nücumu'z-Zahire, s.85. Memluklara iltica eden bu Uyratların akıbeti hakkında bkz. F. Sümer, "Anadolu'da Moğollar", s.66.

77 M. Gül, a.g.m, s.201.
}

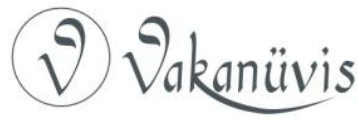


alarak $^{78}$ bölgedeki hâkimiyet mücadelelerinde etkin rol oynamaya devam etmişlerdir. Özellikle Ahmet Celayir ile Kara Yusuf arasındaki mücadelelerde zaman zaman farklı saflarda yer almışlardır. ${ }^{79}$

Moğol istilasının Doğu Anadolu'ya sürüklediği Türk toplulukları arasında Akkoyunlu ve Kara Koyunlu Türkmenlerinin esas kütleleri de vadı. ${ }^{80}$ Bunlardan Kara Koyunlular, İlhanlı hükümdarı Argun (12841292) zamanında ${ }^{81}$ Türkistan'ın Gazgırt bölgesinden ${ }^{82}$ Azerbaycan'a, oradan da Bitlis ve havalisine göç ederek Van Gölü Havzası'nda önemli rol oynayan Türkmen gruplarından birini teşkil edeceklerdir. ${ }^{83}$ Kara Koyunluların Anadolu'ya gelişleri hakkında pek çok rivayet anlatılsa da bunlar içinde Tarih-i Türkmaniye'nin verdiği bilgi kuvvetle muhtemel görünmektedir. Buna göre, 30000 çadırdan müteşekkil olan Kara Koyunlular, Çingiz Han'ın hücumu üzerine Türe Beg adındaki reislerinin idaresi altında Türkistan'dan Maveraünnehr'e ve oradan da İran yoluyla Doğu Anadolu'ya göç etmişlerdir. ${ }^{84}$

Akkoyunlular ise Kitab-ı Diyarbekriyye'nin verdiği bilgiye göre Tur Ali'nin babası Pehlivan Beğ, Hülegü'nün öncü birliklerinin komutanı Çurmağun Noyan ile girdiği bir savaşı kazanarak Rum (Anadolu)'a göç etmiştir. Yine aynı kaynağın verdiği bilgiye göre Akkoyunluların lideri olan Tur Ali'nin buyruğu altında 30000 hanelik kalabalık bir topluluk vardı. İlhanlı hükümdarı Gazan Han'ın Anadolu ve Suriye taraflarına

\footnotetext{
${ }^{78}$ F. Sümer, "Anadolu'da Moğollar", s.139.

${ }^{79}$ Bu konuda geniş bilgi için bkz. Hasan-ı Rumlu, Ahsenü’t Tevarih, (nşr. Mürsel Öztürk) Ankara 2006, s.80, 85.

${ }^{80}$ Bu konuda geniş bilgi için bkz. F. Sümer, Kara Koyunlular, s.34vd; Z. Velidi Togan, a.g.e, s.253.

${ }^{81}$ M. Fuad Köprülü, a.g.e, s.92; i. Hakkı Uzunçarşılı, Anadolu Beylikleri ve Akkoyunlu Karakoyunlu Devletleri, Ankara 1984, s.180.

82 Sözü edilen yer Oğuzlar'ın en eski yurdu olup Karaçuk dağlarının bir bölümünü ihtiva etmektedir.

${ }^{83}$ Bkz, Devletşah, Tezkire-i Devletşah III, (nşr. Necati Lügal), Ankara 1987, s.457.

${ }^{84}$ Bkz. Z. Velidi Togan, a.g.e, s.363; Fahrettin M. Kırzıoğlu, Dede Korkut Oğuznameleri I, İstanbul 1952, s.44; F. Sümer, Kara Koyunlular, s.35vd.
}

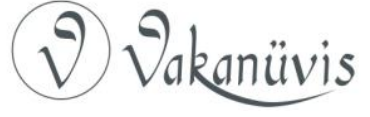


yapmış olduğu seferlerde görev alan Tur Ali, önemli başarılar elde etmiş ve Gazan Han'ın iltifatına mazhar olmuştu. ${ }^{85}$

Van Gölü Havzası'nda yurt tutmuş ve bölgede belli bir dönem hâkimiyet tesis etmiş olan diğer bir Moğol topluluğu ise Sutaylardır. Beyleri Sutay Noyan belli bir dönem Ahlat valiliği de yapmıştır. ${ }^{86}$ MuşAhlat-Aladağ yöresini yaylak olarak kullanan Sutaylara mensup bazı Moğol kabileleri, kısa süre sonra Van ve çevresinde hakimiyet kuracak olan Kara ve Ak Koyunlu Türkmen federasyonları içerisinde yer alacaklardır. ${ }^{87}$ Sutayların adı bugün Ahlat ve çevresinde yöre halkının Sutey Sazlığı ya da Sutey Gediği diye ifade ettiği Sutay Sazlığı ve Sutay Gediği yer adları ile devam etmektedir. ${ }^{88}$ Sutayların diğer bir kısmı olan Baranbaylar ise Orta Anadolu'ya göç ederek, Eretnalılar'ın hizmetine gireceklerdir. ${ }^{89}$

Moğol istilası sırasında Anadolu'ya gelen topluluklardan biri de Celayirlilerdir. Cingiz Han döneminden itibaren hâkimiyet altına alınan bu Moğol boyu ${ }^{90}$ Hülagü'nün ordusunda da önemli bir yer işgal etmekteydi. İlhanlı devletinin yıkılmasından sonra İran, Azerbaycan ve

${ }^{85}$ Bkz. Ebu Bekr-i Tihrani, Kitab-ı Diyarbekriyye I, (Farsça nşr. Necati Lügal-Faruk Sümer), Ankara 1993, s.11vd. Ebu Bekr-i Tihrani, Kitab-ı Diyarbekriyye, (nşr. Mürsel Öztürk), Ankara 2001, s.22; Tufan Gündüz, Anadolu'da Türkmen Aşiretleri (Bozulus Türkmenleri), İstanbul 2010, s.23; John E. Woods, 300 Yıllık Türk Imparatorluğu Akkoyunlular, (nşr. Sibel Özbudun), İstanbul 1993, s.69vd; M. Halil Yinanç, "Akkoyunlular", IA II, s.252vd.

${ }^{86}$ Bkz. Mir Muhammed b. Seyyid Burhaneddin Havendşah Mirhand, Tarih-i Ravzatü's Safa Fi Siretül-Enbiya ve'l-Müluk ve'l-Hulefa V, Tahran 1339, s.480; F. Sümer, "Anadolu'da Moğollar", s.83; Yaşar Yücel, Anadolu Beylikleri Hakkında Araştırmalar II, Ankara 1991, s.5. Sutay Noyan, Diyarbakır valisi Mulay Noyan'ın ölümünden sonra 1312'te Diyarbakır valiliğine atanmıştı. Bkz. M. Halil Yınanç, "Diyarbekir", IA III, s.620; Yaşar Yücel, Kadı Burhaneddin Ahmet ve Devleti (1344-1398) , Ankara 1991, s.31.

${ }^{87}$ Bkz. F. Sümer, "Anadolu'da Moğollar", s.108; Muammer Gül, a.g.m, s.201.

${ }^{88}$ F. Sümer, "Anadolu'da Moğollar", s.143; H. Saraçoğlu, Doğu Anadolu Bölgesi, (eklerharita-1).

${ }^{89}$ Bu konuda geniş bilgi için bkz. Aziz b. Esterabadi, Bezm ü Rezm, (nşr. Mürsel Öztürk), Ankara 2014, s.129, 130, 259; F. Sümer, "Anadolu'da Moğollar", s.108; i. Hakkı Uzunçarşılı, Anadolu Beylikleri ve Ak Koyunlu Karakoyunlu Devletleri, s.158; Kemal Göde, a.g.e, 102,112.

90 Bkz. Moğolların Gizli Tarihi, s.66, 84, 87, 138.

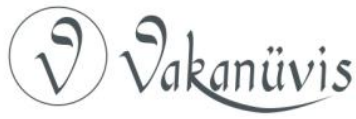


Doğu Anadolu'da Celayirliler, Uyratlar ve Çobanlılarla hâkimiyet mücadelesine girişeceklerdir. ${ }^{91}$ Van ve yöresinin Timur'un bölgeyi ele geçirmesine kadar Celayirlilere bağlı beyler tarafından yönetildiği tespit edilmektedir. ${ }^{92}$ Nitekim 1385 'te Celayir hükümdarı Sultan Üveys döneminde Ahlat valisi görevini yürüttüğü sırada Timurtaş ile ittifak içerisinde olduğunun anlaşııması üzerine idam edilmiş olan Emir Hızır Şah adlı bir Türk beyinin bulunduğu görülmektedir. ${ }^{93}$

Bunların dışında muhtelif zamanlarda Çağatay ve Cuci İmparatorlukları'ndan pek çok unsurlar da ilhanlı sahasına göç etmişlerdir. ${ }^{94}$ Bu Moğol boy ve oymaklarının bir süre sonra Müslüman olmaları, nüfus olarak Türkler arasında azınlıkta kalmaları ve nihayet kültürel açıdan Türklerden daha geri bir kültürel iklimi temsil etmelerinden dolayı Türkleştikleri ve Türkçe konuştukları görülmektedir. ${ }^{95}$

Illhanlı devletinin yıkılması Yakındoğu'ya gelmiş olan Moğol kabilelerinin etkin rolünü ortadan kaldırdı. İran, Azerbaycan ve Doğu Anadolu'da ortaya çıkan hâkimiyet mücadeleleri ${ }^{96}$ ve akabinde teşekkül eden Kara Koyunlu ve Akkoyunlu Türkmen devletlerinin bölgenin siyasi geleceğinde söz sahibi olmaları bu Moğol kabilelerinin kendi aralarında bölünmelerine ya da yerlerini yeni Oğuz-Türkmen gruplara bırakmalarına sebep olmuştur. ${ }^{97}$ Timur tarafından XV. asrın başlarında Türkistan'a götürülen Orta Anadolu'da yurt tutmuş olan

91 Bu konu hakkında geniş bilgi için bkz. Zeyl-i Camiü't-Tevarih Reşidi Zübdetü't-Tevarih (Fransızca trc.), s.120; Matlau's-Sadeyn I, s.132vd; Ravzatü's Safa V, s.541vd; Habibü'sSiyer III, s.225vd; J. A. Boyle, "Dynastic and Political History of the Ilkhans", s.414; F. Sümer, "Anadolu'da Moğollar", s.96.

${ }^{92}$ Bkz. M. Beşir Aşan, XIV. Yüzyılda Van ve Yöresi, FÜSBE (Basılmamış Doktora Tezi), Elazığ 1992, s.20.

${ }^{93}$ Bkz. Ravatu's-Safa V, s.572; Abdürrahim Şerif, a.g.e, s.64vd. Ayrıca kitabe için bkz. Abdürrahim Şerif, a.g.e, şekil 9.

${ }^{94}$ Bkz . M. Fuad Köprülü, a.g.e, s.92; Z. Velidi Togan, a.g.m, s.103.

${ }^{95}$ Bkz. V. V. Barthold, İslam Medeniyeti Tarihi, (nşr. M. Fuad Köprülü), Ankara 1973, s.66, 199; Peter B. Golden, a.g.e, s.302vd.

${ }^{96}$ Bu konuda geniş bilgi için bkz., Habibü's-Siyer III, s.221vd; B. Spuler, a.g.e, s.144-154;

F. Sümer, "Anadolu'da Moğollar", s.95-143, F. Sümer, Kara Koyunlular, s.33vd.

${ }^{97}$ C. Cahen, a.g.e, s.308.

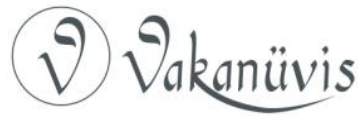


Kara Tatarlar ${ }^{98}$ hariç diğer Moğol unsurlar Türkleşmişlerdir. ${ }^{99}$ Bunlardan Azerbaycan ve Anadolu coğrafyasında bugün hala devam eden etnik, topografik ve filolojik izler bulunmaktadır. ${ }^{100}$

${ }^{98}$ Hülegü’nün İran'agelişi sırasında Anadolu 'ya gelmiş olan bu Kara Tatarlar, Ebu Said'in ölümünden sonra eşkiyalık yapmaya başladılar. Farklı gruplara ayrılarak değişik bölgelerde yurt tuttular. Bunların bir kısmı da Trabzon civarında yurt tutmuştu. İlhanlı devletinin yıkılışına kadar da bu devlete bağlı kaldılar ve çok sayıda köle vermekteydiler. [Bkz. Bkz., Jakob P. Fallmerayer, a.g.e, s.191.] Yıldırım Bayezid'in Sivas'ı aldığı zamanda Osmanlı ordusuna katıldılar. Timur'un Osmanlı'yı mağlup ettiği zaman bunlar Tokat, Kayseri, Amasya civarında oturmaktaydılar. Timur otuz- kırk bin hane olan bu Kara Tatarları Semerkand'a götürüp sınırlara yerleştirmeyi uygun buldu. Kara Tatarların akıbeti hakkında geniş bilgi için bkz. [Şerefüddin Ali Yezidi, Emir Timur (Zafername), (nşr. Ahsen Batur), İstanbul 2013, s.409vd; Nizamüddin Şami, Zafername, (nşr. Necati Lugal), Ankara 1987, s.328vd; ibni Arabşah, Acaibü'l Makdur, (nşr. Ahsen Batur), İstanbul 2012, s.346vd; í. Aka, Timur ve Devleti, Ankara 1991, s.30.] XV. asrın başlarında İspanya kralı tarafından Timur'a gönderilen Clavijo, Damgan civarına geldiğinde öldürülen insanların kafalarından kuleler yapılmış olduğunu ve bunların Akkoyunlular olduğunu söylese de aslında bunlar Kara Tatarlara aittir. [Bkz., Ruy Conzales de Clavijo, Anadolu, Orta Asya ve Timur, (nşr. Ö. Rıza Doğrul), İstanbul 1993, s.110vd.] Hoca Sadettin Efendi ise bu Kara Tatarların Hülegü tarafından Anadolu'ya yerleştirildiklerini, Ebu Said'in ölümüyle baş gösteren kargaşa ortamında sayıları elli iki tümen olan bu Kara Tatarların farklı yaylak ve kışlaklara dağıldığından bahsederek, Yıldırım Bayezid tarafından Osmanlı hizmetine alındıklarını belirtmektedir. [Bkz., Hoca Sadettin Efendi, Tacü't-Tevarih I, (nşr. İ. Parmaksızoğlu), Ankara 1992, s.333.]Diğer taraftan Hoca Sadettin Efendi, Timur'un bunların büyük kısmını götürmesinden sonra geriye kalanların i̇skilp civarında bulunduklarını ve buradan alınarak Filibe yöresine iskân edildiklerini belirtmektedir. [Bkz. Hoca Sadettin Efendi, Tacü't-Tevarih II, (nşr. i. Parmaksızoğlu, Ankara 1992, s.98.] Nitekim Osmanlı arşiv belgelerinde de Tatar, Tatarlar, Tatarlı, Tatarlu, Tataran gibi isimlerde cemaatlere Balkan ve Trakya bölgesinde rastlanmaktadır. Bkz. Cevdet Türkay, a.g.e, s.158,714.

${ }^{99}$ B. Spuler, İran Moğolları, s.497vd; M. Fuad Köprülü, Anadolu'da İslamiyet, Ankara 2012, s.53; B. Y. Viladimirtsov Moğolların İctimai Teşkilatı Moğol Göçebe Feodalizmi, (nşr., Abdülkadir İnan), Ankara 1995 s.184vd. Bu hakikat Osmanlı arşiv belgelerinde de takip edilebilmektedir. Nitekim Moğol aşiretlerinden Celayir, Tatar, Sulduz vs. den yörükan ya da Türkmen taifesi olarak bahsedilirken aynı şekilde Muğan, Muğanan, Muğanlı, Muğanlu, Muğulcalı gibi aşiretler de Türkmen olarak kaydedilmiştir. [Bkz Cevdet Türkay, a.g.e, s. 37, 124, 158, 277.] Diğer taraftan Kara Tatarlar da pek çok bakımdan Türkmenleşmişlerdi. Çağataylar bu Kara Tatarlara "Kara Tatar Türkmenleri"adını veriyorlardı. Bkz., F. Sümer, "Anadolu'da Moğollar", s.130.

${ }^{100}$ Bkz. Osman G. Özkuzugüdenli, "Moğollar", Di̇A XXX, (ístanbul 2005), s.228. Ayrıca bkz. W. Barthold, Türk-Moğol Ulusları Tarihi, s.23vd.

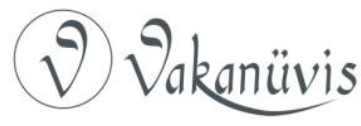


Kuzeyde Kafkaslar ve Azerbaycan üzerinde meydana gelen ilhanlıAltınorda savaşları ile güneyde daha çok Doğu ve Güneydoğu Anadolu ekseninde zuhur eden ilhanlı-Memlûklu mücadeleleri Van Gölü Havzası'nda yerleşik Türk ve Moğol boy ve oymaklarının çevre bölgelere dağılmasına sebep olduğu gibi iki asır kadar sürecek olan bu dışa göç hareketi güneyde ve doğuda Zağros civarındaki Kürt aşiretlerinin özellikle Ahlat ve Diyarbekir yörelerine doğru ilerlemelerinin de önünü açacaktır. ${ }^{101}$

Yukarıda bahsi geçen dışarıya göç hareketlerine rağmen Van Gölü Havzası'nın da içerisinde bulunduğu Doğu Anadolu Bölgesi hakkında "Türkmen Ülkesi" kavramı kullanılmıştır. Bu gerçek XIII. yüzyılda Marco Polo, Anadolu'nun bu yörelerinden "Türkomania" yani Türkmen Ülkesi olarak söz etmektedir. ${ }^{102}$ Aynı asırda bölgeye gelen Zekeriya el Kazvini (ölümü 1283) ise Ahlat'ta Türkçe, Farsça ve Ermenice'nin konuşulduğunu söyler $\mathrm{ki}^{103}$ bu da artık yörede Arapça'nın yerini Türkçe'nin aldığını göstermektedir. ${ }^{104}$ Çünkü henüz Türk fütühatından önce yani 1046 yılında bölgeden geçen Nasıri Hüsrev, burada Arapça, Farsça ve Ermenice'nin konuşulduğunu belirtmekteydi. ${ }^{105}$ Celalettin Harzemşah, Ahlat muhasarası sırasında şehirden mektup getiren bir kadın elçiyle Türkçe, Farsça ve Ermenice konuşabiliyordu. ${ }^{106}$ Diğer taraftan Ahlat mezartaşlarını inceleyen Beyhan Karamağralı, kitabelerde kullanılan Farsça ve Arapça ifadelerin yanlışlıklarına dikkati

${ }^{101}$ Claude Cahen, yer değiştiren bu Kürt gruplarının daha önce hiç görülmedikleri Ermeni yörelerine sızdıklarını belirtmektedir. Bkz. C. Cahen, a.g.e, s.308. Bu Kürt grupları nicelik olarak şehir ve kasabalarda azınlıkta kaldıklarından Türkleşmişlerdir. Bkz. O. Turan, Doğu Anadolu Türk Devletleri Tarihi, s.147.

${ }^{102}$ Marko Polo Seyahatnamesi I, (nşr. Filiz Dokuman), Tarihsiz, s.20vd; Abdulhaluk Çay vd, Türk Milli Bütünlüğü içerisinde Doğu Anadolu, Ankara, 1986, s.37. Ancak Pelliot'a göre Marco Polo, Turcomanie derken daha çok iç ve Doğu Anadolu'yu kast etmiştir. Bu konuda geniş bilgi için bkz. Tuncer Baykara, "Doğu Anadolu= Türkmenia" (Türkmen Ülkesi)", Atsız Armağanı, İstanbul 1976, s.61-66.

${ }^{103}$ F. Sümer, Doğu Anadolu'da Türk Beylikleri, Ankara 1998, s.53.

${ }^{104}$ O. Turan, Doğu Anadolu Türk Devletleri Tarihi, s.146.

${ }^{105}$ Bkz. Nasır-ı Hüsrev, Sefaretname, (nşr. Abdülvehhab Tarzi), İstanbul 1994, s.10.

${ }^{106}$ Bkz. en-Nesevi, (O. Houdas), s.322vd; en- Nesevi, s.123; O. Turan, Doğu Anadolu Türk Devletleri Tarihi, s.147.

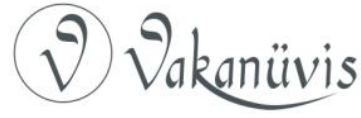


çekerek bölge halkının aslında bu iki dili iyi bilmediğini ve sadece kitabelerde kullanılmış olabileceğini belirtmektedir. ${ }^{107}$

XV. yy'da Uzun Hasan'la ittifakli görüşmesi için gönderilmiş olan Venedik elçisi Contarini, Uzun Hasan'ın ülkesinden bahsederken Turcomania ifadesini kullanarak aslında Doğu Anadolu'nun bir Türk yurdu olduğunu dile getirmiştir. ${ }^{108}$ Yine aynı dönemlerde bölgeye gelen bir diğer Venedik elçisi J. Barbaro ise yöreyi Türkmen ülkesi olarak tanımlar. ${ }^{109}$ Bölgedeki Türk nüfusunun baskın oluşu uzun bir süre daha devam etmiştir. Çünkü XVI. asırda Osmanlı Tapu Tahrir Defterleri'ne göre Doğu ve Güneydoğu Anadolu'daki cemaatlerin \% 80'den fazlası Türklerden oluşmaktaydı. ${ }^{110}$ Bundan bir asır sonra yani XVII. asırda bölgeye gelen Evliya Çelebi ise meşhur Seyahatnamesi'nde, Ahlat'ta konuşulan dilin Çağatayca'ya ve Moğol diline yakın bir lehçe olduğunu söyler ki bu da bölgenin etnik yapısı hakkında önemli bir kayıt niteliği taşımaktadır. ${ }^{111}$

${ }^{107}$ B. Karamağralı, Ahlat Mezartaşları, Ankara 1972, s.106.

${ }^{108}$ Caterino Zeno ve Ambrogio Contarini, Seyahatnameler (Doğu'da Venedik Elçileri), (nşr. Tufan Gündüz), İstanbul 2006, s.135.

${ }^{109}$ Josaphat Barbaro, Anadolu'ya ve Iran'a Seyahat, (nşr. Tufan Gündüz), İstanbul 2005, s103; Daha çok yayla ve dağlarla kaplı olan bu vatan köşesinin nasıl Türkmen Ülkesi olduğunu anlamak da kolaydır. Anadolu'ya gelen yerleşik hayata alışık Türkler, kendileri için daha elverişli şartlar taşıyan batı yöresine girmişlerdir. Oysa göçebe hayat süren ve daha ziyade hayvancılığa dayalı bir iktisadi hayata sahip Türkmen boyları için bu yörenin yaylaları son derece önemli idi. [Bkz., Abdulhaluk Çay vd, Türk Milli Bütünlüğü Içcerisinde Doğu Anadolu, s.36.] Doğu Anadolu dağlarının bu özelliği birçok Türk destanlarına da konu olmuştur. Örneğin Oğuz Han'ın da bir zamanlar Alatağ ve Ağdıböri (Ağrı) dağlarında yayladığı destanda anlatılmaktadır. Bkz., Z.Velidi Togan, Oğuz Destanı, İstanbul 1972, s.30-32.

${ }^{110}$ Bkz. Ali Rıza Özdemir, Kayıp Türkler (Etnik Coğrafya Bakımından Kürtleşen Türkmen Aşiretleri), Ankara 2013, s.116. Ayrıca aynı asırda Doğu Anadolu Bölgesi'ndeki şehirlerin mahallelerinin isimleri büyük oranda Türkçe kelimelerden oluşmaktaydı. Bkz. Refet Yinanç, "XV. Yüzyılda Doğu Anadolu Şehirlerinin Mahalle Adları", Türk Yer Adları Sempozyumu Bildirileri (11-13 Eylül 1984), Ankara 1984, s.225-232; Abdulhaluk Çay vd, Türk Milli Bütünlüğ Içerisinde Doğu Anadolu, s.48vd

${ }^{111}$ Bkz., Evliya Çelebi, Seyahatname I/4, s. 193.

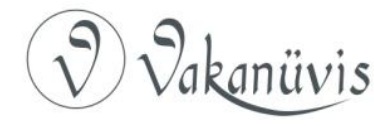




\section{Kaynakça}

Aka, İsmail, "Anadolu'dan İran'a Göçler", Tarihten Günümüze Türk-İran ilişkileri Sempozyumu (16-17 Aralık 2002 Konya), Ankara 2003.

Alasania, Guili, "Gürcistan Kıpçakları", Türkler II, Ankara 2002.

Aziz b. Esterabadi, Bezm ü Rezm, (nşr., Mürsel Öztürk), Ankara 2014.

Barbaro, Josaphat, Anadolu'ya ve Iran'a Seyahat, (nşr. Tufan Gündüz), istanbul 2005.

Barthold, V. V., İslam Medeniyeti Tarihi, (nşr. M. F. Köprülü), Ankara 1973.

Baykara, Tuncer, "Doğu Anadolu= Türkmenia" (Türkmen Ülkesi)", Atsız Armağanı, İstanbul 1976.

Baykara, Tuncer, Hınıs ve Malazgirt Sancakları Yer Adları (XVI. yy), Ankara 1991.

Beygu, A.Şerif, Ahlat Kitabeleri, İstanbul 1932.

Beysanoğlu, Şevket, Anıtları ve Kitabeleri ile Diyarbekir Tarihi I, Ankara 1987.

Hafız-ı Ebru, Chroniqe des Rois Mongols en İran, (Zeyl-i Camiü't-Tevarih Reşidi Zübdetü't-Tevarih), (nşr. K. Bayani), Paris 1936.

Cahen, C., Osmanlılardan Önce Anadolu'da Türkler, (nşr. Y. Moran), İstanbul 1984.

Caterino Zeno ve Ambrogio Contarini, Seyahatnameler (Doğu'da Venedik Elçileri), (nşr. Tufan Gündüz), İstanbul 2006.

Cöhce, Salim, "Doğu Karadeniz Bölgesinin Türkleşmesinde Kıpçakların Rolü", I. Tarih Boyunca Karadeniz Kongresi Bildirileri (13-17 Ekim1986), Samsun 1988.

Cüveyni, Alaaddin Ata Melik, Tarih-i Cihangüşa I, (nşr., Mürsel Öztürk), Ankara 1998.

Çay, Abdulhaluk vd, Türk Milli Bütünlüğü Iç̧erisinde Doğu Anadolu, Ankara, 1986.

Çay, Abdulhaluk, Anadolu'da Türk Damgası (Koç-koyun HeykelMezartaşları ve Türklerde Koç-Koyun Meselesi), Ankara 1983.

Çoruhlu, Yaşa, Türk Sanatında Hayvan Sembolizmi- I, İstanbul 1995.

D’ohsson, M. Baron C. Moğol Tarihi, (nşr. Ekrem Kalan vd.), İstanbul 2006.

Devletşah, Tezkire-i Devletşah III, (nşr., Necati Lügal), Ankara 1987.

Diyarbekirli, Nejat, Hun Sanatı, İstanbul 1972.

Durak, Neslihan, "ilhanlılar Döneminde Aladağ Çevresi", I. Uluslararası Ahlat-Avrasya Bilim, Kültür ve Sanat Sempozyumu (23-25 Ağustos 2012), istanbul 2013.

Ebu Bekr-i Tihrani, Kitab-ı Diyarbekriyye I, (Farsça nşr. Necati Lügal-Faruk Sümer), Ankara 1993

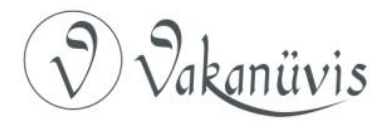


Ebu Bekr-i Tihrani, Kitab-ı Diyarbekriyye, (nşr., Mürsel Öztürk), Ankara 2001.

Ebu'l Kasım Abdullah b. Muhammed Kaşani, Tarih-i Olcaytu, (nşr. M. Hemblu), Tahran 1348.

Ebu'l-Fida, Takvimü'l-Büldan, (nşr. Ramazan Şeşen), İstanbul 2017.

Muhammed en-Nesevi, Celalüttin Harzemşah, (nşr. Necip Asım), İstanbul 1934.

Muhammed en-Nesevi, en-Nesevi Siretü's-Sultan Celaleddin Mengüberti, (nşr. O. Houdas), Paris 1891.

Eröz, Mehmet "Sosyolojik Yönden Türk Yer Adları", Türk Tarihi Dergisi, Sayı:12, (Şubat1986).

Eröz, Mehmet, Doğu Anadolu'nun Türklüğü, İstanbul 1982.

Eröz, Mehmet, Hırıstiyanlaşan Türkler, Ankara 1983.

Evliya Çelebi, Seyahatname I/4, (S. Ali Kahraman-Yücel Dağlı), İstanbul 2010.

Fallmerayer, J. P., Trabzon Imparatorluğunun Tarihi, Ankara 2011.

Golden, Peter B. "Cumanica I: The Qıpcaqs in Georgia", Nomands and their Neighbours in the Russian Steppe-Turks-Khazars and Qipcahaqs, Variorum 2003.

Golden, Peter B., Türk Halkları Tarihine Giriş, (nşr. Osman Karatay), İstanbul 2012.

Göde, Kemal, Eratnalılar (1321-1387), Ankara 2000.

Gökbel, Ahmet, Kıpçak Türkleri, İstanbul 2000.

Gregory Ebu'l Faraç, Ebu'l Faraç Tarihi I, (Türkçe nşr. Ömer Rıza Doğrul), Ankara 1999.

Gül, Muammer, "ilhanlılar Döneminde Diyarbakır", I. Uluslararası Oğuzlardan Osmanlı'ya Diyarbakır Sempozyumu ( 20-22 Mayıs 2004 Diyarbakır ), Diyarbakır 2004.

Gül, Muammer, Orta Çağlarda Doğu ve Güneydoğu Anadolu ( Tarihi Arka Plan ve XIII -XIV Yüzyıl Moğol Hâkimiyeti), İstanbul 2010.

Gündüz, Tufan, Anadolu'da Türkmen Aşiretleri (Bozulus Türkmenleri), İstanbul 2010.

Gürdal, İbrahim, Köylerimiz (1968'e kadar), (İçişleri Bakanlığı Başbakanlık Basımevi), Ankara 1968.

Halaçoğlu, Yusuf, Anadolu'da Aşiretler, Cemaatler, Oymaklar (1453-1650) I-IV, Ankara 2009.

Halperin, Charles J. "The Kipçhak Connection: the Ilkhans, the Memluks and Ayn Jalut", Bulletin of The School of Oriental and African Studies, University of London, vol. 63, No.2 (2000), s.234.

Hamd-Allah Mustawfi Kazwini, Nuzhat-Al- Qulub, (nşr., G.Le Strange), London 1915, s.100.

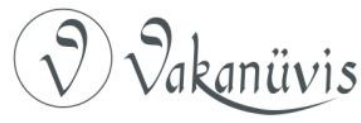


Hasan-ı Rumlu, Hasan-ı Rumlu, (nşr., Mürsel Öztürk) Ankara 2006.

Hoca Sadettin Efendi, Tacü't-Tevarih I, II, (nşr.,i. Parmaksızoğlu), Ankara 1992.

İbn Bibi, El-Evamirüll-Ala'iyye fi'l-Umuri'l Ala'iyye, (nşr. Mürsel Öztürk), Ankara 2014.

Selçukname, (nşr. M. Halil Yinanç), İstanbul 2007, s.139;

İbn Şeddad, Bay-bars Tarihi, (nşr. M. Şerafettin Yaltkaya), İstanbul 1941.

İbni Arabşah, Acaibü'l Makdur, (nşr., Ahsen Batur), İstanbul 2012.

İbni Tagrıberdi, En Nücumu'z-Zahire, (nşr., Ahsen Batur), İstanbul 2013.

İbnü'l- Esir, El-Kamil fi't Tarih XII, (nşr. Abdulkerim Özaydın), İstanbul 1987.

İbnü'l-ibri Ebu'l- Ferec, Tarih-i Muhtasari'd-Düvel, (nşr., Şerafeddin Yaltkaya), Ankara 2011.

İnanç, M.Halil, "Celayir", IA III.

Kafesoğlu, Ibrahim, "Ahlat ve Çevresinde 1945'te Yapılan Tarihi ve Arkeolojik Tetkik Seyahat Raporu", iÜEF Tarih Dergisi I/1-2, İstanbul 1944.

Kafesoğlu, İ., Türk Milli Kültürü, İstanbul 1996.

Kalafat, Yaşar, Doğu Anadolu'da Eski Türk Inançlarının İzleri, Ankara 1999.

Kanat, Cüneyt, " Gazan Han Zamanında Memluk Devletine Iltica Eden Uyratlar", Tarih İncelemeleri Dergisi XV, İzmir 2000.

Karamağralı, B., Ahlat Mezartaşları, Ankara 1972.

Karamağralı, H., "Büyük Bir Kültür ve Sanat Merkezi Olan Ahlat", Türkler, Ankara 2002.

Kayabalı, İsmail vd., Beş Nehir (Çoruh, Kür, Aras, Dicle, Fırat) Boyunun Türklüğ̈̈, Ankara 1990.

Kaymaz, N., Anadolu Selçuklularının Inhitatında Idare Mekanizmasının Rolü, Ankara 2011.

Keçiş, Murat, Trabzon Rum Imparatorluğu ve Türkler (1204-1404), Ankara 2013.

Kemalu'd-din Abdürrezzak Semerkandi, Matlau's-Sadeyn Mecmua-ı Bahreyn I, (nşr., Abdu'l Hüseyin Nevani), Tahran 1353.

Kerimüddin Mahmud-i Aksarayi, Müsameretü'l-Ahbar, (nşr. Mürsel Öztürk), Ankara 2000.

Kıldıroğlu, Mehmet, Kırgızlar ve Kıpçaklar, Ankara 2013.

Kılıç, Orhan, XVI. Yüzyılda Adilcevaz ve Ahlat (1534-1605), Ankara 1999.

Kırzıoğlu, M. Fahrettin, Dede Korkut Oğuznameleri I, İstanbul 1952.

Kırzıoğlu, M. Fahrettin, Yukarı Kür ve Çoruk Boyları'nda Kıpçaklar (Ahıska/Çıldır Eyaleti Tarihi'nden), Ankara 1992.

Köprülü, M. Fuad, "Harizmşahlar", IA V.

Köprülü, M. Fuad, Osmanlı Imparatorluğunun Kuruluşu, (nşr., O. Köprülü), İstanbul 2012.

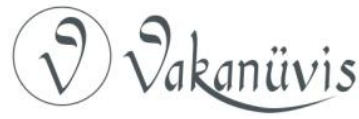


Kurat, A. Nimet, IV-XVIII. Yüzyıllarda Karadeniz'in Kuzeyindeki Türk Kavimleri ve Devletleri, Ankara 2002.

Marco Polo, Dünyanın Hikâye Edilişi, (nşr., Işık Ergüden), İstanbul 2003.

Marko Polo Seyahatnamesi I, (nşr., Filiz Dokuman), Tarihsiz.

Mehmet Neşri, Kitab-ı Cihannüma I, (nşr. F. Reşit Unat-M. Altay Köymen), Ankara 1987.

Minorsky, V. , Studies in Caucasian History (The Shaddadis of Ani), London 1953.

Mir Muhammed b. Seyyid Burhaneddin Havendşah Mirhand, Tarih-i Ravzatü's Safa Fi Siretü'l-Enbiya ve'l-Müluk ve'l-Hulefa V, Tahran 1339.

Moğolların Gizli Tarihi, (nşr., Ahmet Temir), Ankara 2010.

Müneccimbaşı Ahmed b. Lütfullah, Camiü'd-Düvel II, (nşr. Ali Öngül), İzmir 2000.

Nasır-ı Hüsrev, Sefaretname, (nşr. Abdülvehhab Tarzi), İstanbul 1994.

Nihal, H. - Ahmet Naci, "Anadolu'da Türklere Aid Yer Isimleri", Türkiyat Mecmuası II, İstanbul 1928.

Ocak, A. Yaşar, XIII. Yüzyılda Babailer İsyanı, İstanbul 1980.

Oktay, Hasan, Ermeni Kaynaklarında Türkler ve Moğollar, İstanbul 2007.

Ögel, Bahaeddin, Türk Kültür Tarihine Giriş IV, Ankara 1987.

Özkuzugüdenli, Osman G., "Moğollar", DiA XXX, (İstanbul 2005).

Rasonyi, L., Tarihte Türklük, Ankara 1996.

Reşidü'd-din Fazlullah Hemedani, Tarih-i Mübarek Gazani (Destan-i Gazani), (nşr., Karl Jahn), London 1940.

, Camiü't Tevarih (illhanlılar kısmı), (nşr. İsmail Aka, Mehmet Ersan ve Ahmad Hisamipour Khelejani), Ankara 2013.

Ruy Conzales de Clavijo, Anadolu, Orta Asya ve Timur, (nşr. Ö. Rıza Doğrul), İstanbul 1993.

Sevim, Ali-E. Merçil, Selçuklu Devletleri Tarihi, Ankara 1995.

Sevim, Ali-Yaşar Yücel, Türkiye Tarihi, Selçuklu ve Beylikler Dönemi, Ankara 1989,

Solmaz, Gürsoy, Ermeni Müverrihlerine Göre Moğollar ( Müverrih Kiragos'tan Alınmıştır), (Edvar Dulaurier Tercümesinden), Erzurum 2000.

Spuler, B., Iran Moğolları(Siyaset, idare ve Kültür ilhanlılar Devri), (nşr. Cemal Köprülü), Ankara 2011.

Sümer, Faruk. “ Anadoluda Moğollar”, SAD I, Ankara 1970.

Sümer, F. "Yıva Oğuz Boyuna Dair", Türkiyat Mecmuası IX, İstanbul 1951.

Sümer, F., "Ahlat Şehri ve Ahlatşahlar", Belleten, L/297 (1986).

Sümer, F., "Anadolu'da Moğollar ve Ağaç-eriler", Belleten XXVI.

Sümer, F., "Eski Türk Devletlerinde Ağa Ünvanı", Türk Dünyası Araştırmaları, Sayı: 38, İstanbul (Ekim)1985.

Sümer, F., Doğu Anadolu'da Türk Beylikleri, Ankara 1998.

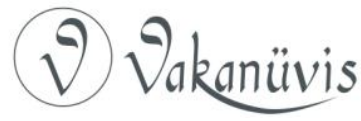


Sümer, F., Kara Koyunlular, Ankara 1992.

Sümer, F., Oğuzlar (Türkmenler), Tarihleri, Boy Teşkilatı, Destanları, İstanbul 1999.

Şerfhan Bitlisi, Şerefname, (nşr. M. Emin Bozarslan), İstanbul 1990.

Tabak, N., Ahlat Türk Mimarisi, İstanbul 1972.

Taneri, A., Celalu'd-din Harizmşah ve Zamanı, Ankara 1977.

Tellioğlu, İbrahim, Osmanlı Hâkimiyetine kadar Doğu Karadeniz'de Türkler, Trabzon 2004.

Temir, Ahmet, "Sulduz/Suldus", IA XI.

Togan, Z. Velidi, Umumi Türk Tarihine Giriş, İstanbul 1981.

Turan, Osman, Doğu Anadolu Türk Devletleri Tarihi, İstanbul 2009.

Turan, O., Selçuklular Zamanında Türkiye, İstanbul 2010.

Türkay, Cevdet, Başbakanlık Arşivi Belgelerine Göre Osmanlı Imparatorluğunda Oymak, Aşiret ve Cemaatler, İstanbul 1979.

Uzunçarşılı, İ. Hakkı, "Emir Çoban Soldoz ve Demirtaş", Belleten XXXI/124.

Uzunçarşılı, i. Hakkı, Osmanlı Devlet Teşkilatına Methal, Ankara 1998.

Uzunçarşılı, I..H., Osmanlı Devlet Teşkilatına Methal, Ankara 1998.

Uzunçarşılı, i.Hakkı, Anadolu Beylikleri ve Akkoyunlu Karakoyunlu Devletleri, Ankara 1984.

Ürekli, Muzaffer, "Celayirliler", DiA VII.

Müverrh Vardan, "Türk Fütühatı Tarihi", (889-1169)", (nşr. Hrand D. Andreasyan), iÜEFY, Tarih Semineri Dergisi I/2, İstanbul 1937.

Viladimirtsov, B. Y., Moğolların İctimai Teşkilatı Moğol Göçebe Feodalizmi, (nşr., Abdülkadir İnan), Ankara 1995.

Woods, John E., 300 Yıllık Türk Imparatorluğu Akkoyunlular, (nşr. Sibel Özbudun), İstanbul 1993.

Yaşa, Recep, Bitlis'te Türk İskânı (XII. ve XIII. Yüzyıl), Ankara 1992.

Yazıcızade Ali, Tevarih-i Ali Selçuk, (nşr. Abdullah Bakır), İstanbul 2009,

Yinanç, M. Halil, "Akkoyunlular", IA II.

Yinanç, M. Halil, "Diyarbekir", IA III.

Yinanç, Refet, Dulkadir Beyliği, Ankara 1989.

Yorulmaz, Osman, Geçmişten Günümüze Kanglı Türkleri, İstanbul 2012.

Yuvalı, Abdulkadir, "Anadolu'nun Türkleşmesi ve Moğollar", Türk Dünyası Araştırmaları, S: 38, İstanbul Ekim-1985.

Yuvalı, Abdulkadir, "ilhanlıların Anadolu Politikası ve Doğu Anadolu Şehirlerinin Vergi Potansiyeli”, XI. Türk Tarih Kongresi II, Ankara 1994.

Yuvalı, Abdulkadir, Ilhanlılar Tarihi I, Kayseri 1995.

Yücel, Mualla Uydu, ilk Rus Yıllıklarına Göre Türkler, Ankara 2002.

Yücel, Yaşar, Kadı Burhaneddin Ahmet ve Devleti (1344-1398), Ankara 1991.

Yücel, Yaşar, Anadolu Beylikleri Hakkında Araştırmalar II, Ankara 1991.

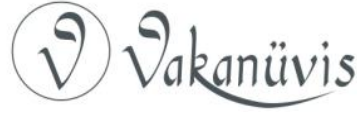

